\title{
IAMJ
}

INTERNATIONAL

AYURVEDIC

MEDICAL JOURNAL

ISSN: 2320-5091

Impact Factor: 6.719

\section{MANAGEMENT OF ORAL SUBMUCOSAL FIBROSIS (OSMF) WITH PANCHGAVYA SHUKTA SHODHAN GANDUSHA AS A DINACHARYA PROCEDURE}

\author{
Jaiminikumar Shashank Rasane ${ }^{1}$, Sudeep Menon², Ashutosh B Patankar³ \\ ${ }^{1}$ (B.A.M.S) M.D. (Scholar Swasthavritta), M.D., Ph.D. (Scholar) (Swasthavritta) \\ ${ }^{2}$ Associate Professor, Department of Swasthavritta and Yoga \\ ${ }^{3}$ M.D. (Ayu), Ph.D. (Ayu), Ayurved Samhita and Siddhant \\ Bharati Vidyapeeth Deemed to be University College of Ayurved, Pune-411038
}

Corresponding Author: vdjaiminikumar03@gmail.com

https://doi.org/10.46607/iamj.1209012021

(Published online: January 2021)

Open Access

(C) International Ayurvedic Medical Journal, India 2021

Article Received: 02/01/2020 - Peer Reviewed: 04/01/2021 - Accepted for Publication: 07/01/2021

Check for updates

\begin{abstract}
The rate of tobacco in addition to above conditions consumption in various forms in recent years is viewed as an emerging epidemic. The symptoms of OSMF may include burning sensation in mouth, intolerance to spicy, pain in mouth, changes in color of oral mucosa, difficulty in opening of mouth. Mukha rogas have been mentioned in Ayurved, with various treatment modalities especially Gandusha and is one of the important Upakrama in Dincharya. Panchagavya is prepared by mixing five products of cow and used in traditional many applications. Shukta varga includes acidic and partially alcoholic preparations of self-generated nature. Application of Panchagavya externally can reduce the Kaathinyata (Hardness) under the Twacha (skin) of oral cavity.
\end{abstract}

Keywords: Panchagavya, Shukta, Gandusha, OSMF

\section{INTRODUCTION}

Oral health is an essential part of our overall health cavities and gum disease, and has also been linked to and well-being. Poor oral hygiene can lead to dental Heart disease, Cancer and Diabetes. Maintaining 
healthy teeth and gums is commitment to life. ${ }^{1}$ The continuous chewing of Paan and swallowing of Gutkha, trigger progressive fibrosis in Sub mucosal tissue which is a connective tissue disorder. ${ }^{2}$ OSMF is defined an oral precancerous condition characterized by inflammation and progressive fibrosis of the submucosal tissues resulting in marked rigidity and trismus. ${ }^{3}$ The symptoms may include burning sensation in mouth, intolerance to spicy, pain in mouth, changes in color of oral mucosa, difficulty in opening of mouth, etc. It occurs at any age but is most commonly seen in adolescents and adults especially between 16 and 60 years ${ }^{19}$ Many treatments for Muka Rogas like, Kavala, Lepanas, Kshar karma, Jaluka avacharan etc. has also been mentioned in various samhitas. ${ }^{5}$ Shodhana Gandusha is a purifactory type of Gandusha. This type of Gandusha induces excessive oro-pharyngeal secretions. It is capable of eliminating the morbid Kapha dosha along with the oropharyngeal secretions in the oral cavity. ${ }^{6}$ There is no direct reference of OSMF in Ayurvedic disease classification, but based on its signs and symptoms, etio pathogenesis, site of manifestation etc it can be understood as one of the types of Uttan Vatarakta. ${ }^{7}$

According to Charaka Acharya every disease cannot be named hence here Oral Submucosal fibrosis can be interpreted as Mukha gata Uttan Vatarakta according to the signs and symptoms. ${ }^{7,8}$

Gandusha is a procedure in which medicinal liquid is kept in mouth for a certain period of time without movement inside. It is one of the important Upakrama in Dincharya. ${ }^{9}$

Panchagavya is prepared by mixing five products of cow and used in traditional many applications. The three direct constituents are cow dung, urine and milk. The Cow derived products are curd and ghee. These are mixed in proper ratio, to get the end product Panchagavya..$^{\mathbf{1 0 , 1 1}}$

Shukta-In this preparation acid is produced predominantly instead of alcohol; hence its taste is mainly sour. Shukta varga includes acidic and partially alcoholic preparations of self-generated nature. ${ }^{12,13}$ Application of Panchagavya externally can reduce the Kaathinyata (Hardness) under the Twacha (skin) of oral cavity. ${ }^{14}$ Hence the present study Panchagavya Shukta Shodhana Gandusha as a treatment modality for management of OSMF had been undertaken.

Aim: Assess the role of Panchgavya Shukta Shodhan Gandush as a Dincharya procedure in management of Oral Submucosal Fibrosis.

\section{Objective}

1. Study of Oral Submucosal Fibrosis according to Ayurvedic perspective.

2. Study in detail about Gandusha Karma as a Dincharya Procedure.

\section{Hypothesis}

$\mathrm{H}_{0}$ : - Panchagavya Shukta Shodhan Gandusha has no significant effect in the management of Oral Submucosal Fibrosis (OSMF).

$\mathrm{H}_{1}$ : - Panchagavya Shukta Shodhan Gandusha has significant effect in the management of Oral Submucosal Fibrosis (OSMF).

\section{Review of Literature:}

1. A pilot study on Ayurvedic management of oral submucous fibrosis.- Kundan R. Patel, Manjusha Rajagopala, Dharmendrasinh B. Vaghela, and Ashok Shah Ayu. 2015 Jan-Mar; 36(1): 34-40. doi: $\quad$ 10.4103/0974-8520.169018PMCID: PMC4687236PMID: 26730136.

2. Tulasi a magical herb and a boon for management of oral submucous fibrosis: a clinical study G. Madhulatha, N. Vijayalaxmi, T. Harshavardhan Department of Oral Medicine and Radiology, Meghna Institute of Dental Sciences, Nizamabad, Telangana, India Received: 15 September 2017 Accepted: 19 September 2017.

3. Clinical evaluation of the role of tulasi and turmeric in the management of oral submucous fibrosis: A pilot, prospective observational study. Adit Srivastava, Rahul Agarwal, T. P. Chaturvedi, Akhilesh Chandra, and O. P. Singh J Ayurveda Integr Med. 2015 Jan-Mar; 6(1): 45-49 doi: 10.4103/0975-9476.146563.

\section{Drug Review}

Panchagavya -It was prepared by mixing five products of cow and three direct constituents are cow dung, urine and milk and the remaining two are cow 
derived products, curd and ghee. These all were mixed $\quad$ in equal ratio and then allowed to ferment. ${ }^{10,11}$

Properties-

\begin{tabular}{|c|c|c|c|c|c|}
\hline Drug & Rasa & Guna & Veerya & Vipaka & Doshakarma \\
\hline Goksheera & Madhura & Snigdha & Sheeta & Madhura & Vata-Pitta Shaman \\
\hline Godadhi & Amla & Guru & Ushna & Amla & Vata Shaman \\
\hline Gomaya Rasa & Kashaya,Tikta & Laghu & Sheeta & Katu & Kapha-Pitta Shaman \\
\hline Gomutra & Katu,Lavana & $\begin{array}{l}\text { Ruksha, } \\
\text { Tikshna }\end{array}$ & Ushna & Katu & Kapha-Vata Shamana \\
\hline
\end{tabular}

Shukta Kalpana - According to Sharangdhar Samhita when liquid associated with Kanda, Mula, Phala, Sneha and Lavana are allowed to ferment in vessel that fermented liquid is known as Shukta. In this preparation, acid is produced predominantly instead of alcohol; hence its taste is mainly sour. ${ }^{12,13}$
According to Dalhana, when Madya group of preparations turn into acidic on keeping for longer period and masking other tastes then these are known as Shukta. Yadavaji also has defined Shukta, as Madya group of preparations or any sweet liquid when become spoiled and develop acidic taste or prepared in acidic liquid by fermentation i.e. known as Shukta. ${ }^{12,13}$

\begin{tabular}{|l|l|l|l|l|l|}
\hline Drug & Rasa & Guna & Veerya & Vipaka & Dosha karma \\
\hline Shukta & Amla & Tikshna, Sara & Ushna & Amla & Pittavardhak, Vatashamak \\
\hline
\end{tabular}

Added Dravyas

This was prepared by mixing with the below mentioned drugs.

Properties $^{26}$

\begin{tabular}{|l|l|l|l|l|l|}
\hline Drug & Rasa & Guna & Virya & Vipaka & Doshakarma \\
\hline Haridra & Tikta, Madhur & Laghu,Ruksha & Ushna & Katu & Kapha-Pittaghna \\
\hline Rajika & Katu & Teekshna & Ushna & Katu & Kapha-Vaataghna \\
\hline Tulasi & Katu,Tikta & Laghu, Snigdha, Tikshna & Ushna & Katu & Kapha-Vaataghna \\
\hline
\end{tabular}

\section{Methodology}

\section{Study Design}

Clinical trial on 25 patients diagnosed with OSMF had been selected based on the inclusion criteria with age group of 16-60 years irrespective of both sex. Investigations and the assessment parameters were recorded on the basis of standard method and had been analyzed statistically using paired t test and Wilcoxon test. Patients had been subjected to Shodhan Gandusha for a maximum period of 15 days. Follow up on $7^{\text {th }}, 15^{\text {th }}$ day and post up follow up was done on $21^{\text {st }}$ and $30^{\text {th }}$ day.

\section{Source of Data}

Patients fulfilling the inclusion criteria had been selected for the study from the OPD and IPD of Bharati
Vidyapeeth (Deemed to be University) College of Ayurved and Hospital, Katraj, Dhankawadi, Pune.

Standard Operating Procedure for Panchagavya Shukta And Gandusha Karma

Contents: Panchagavya (Fresh cow urine, dung and milk and cow derived Curd and Ghee) and Haridra, Rajika, Tulasi patra.$^{\mathbf{1 3}}$

Researches on Haridra and Tulasi applications locally for OSMF has already been conducted and proven. ${ }^{22}$, 23

Procedure for Panchagavya Shukta:- Fresh cow urine, dung and milk were collected from local cow farm using sterile container and stored in refrigerator. Cow's curd and ghee (clarified butter) were obtained from Go Shala, Pune. Equal volume of cow urine, dung and milk, curd and ghee were added and was 
mixed properly and then filtered through a muslin cloth. Panchagavya and contents of Shukta like Haidra, Rajika, Tualsi Patra and Lavana were mixed together and was placed in glass vessel for 3 days for fermentation i.e. (Sandhan Karma). The mixture was filtered and stored in Air tight glass container. ${ }^{13}$

\section{Gandusha Procedure: -}

The patient with concentrated mind and face slightly lifted up should be asked to hold the medicated liquid in his mouth without doing any movement inside. Patient should be advised not to drink the liquid and hold it until the mouth gets filled with oro-pharyngeal secretions (Kapha) and watery discharge (Jalasrava) appears from the nose (Nasa) and the eyes (Netra). ${ }^{\mathbf{1 4}}$, $15,16,17,18$.

\section{Authentication and Standardization -}

It was done at Savitribahi Phule, Pune University.

Intervention:

\begin{tabular}{|l|l|}
\hline Drug & Panchagavya Sukta \\
\hline Dose & $10-20 \mathrm{ml}$. \\
\hline Kala (Time) & Prataha Kala 5-7 minutes after Dantadhavan \\
\hline Method & Shodhan Gandusha \\
\hline Duration of treatment & 15 days \\
\hline Follow up & $7^{\text {th }}$ and $15^{\text {th }}$ day \\
\hline Post up follow up & $21^{\text {st }}$ and $30^{\text {th }}$ day \\
\hline Total period of study & 30 days \\
\hline
\end{tabular}

\section{Statement of Limitations:}

\section{Inclusion Criteria}

1. Patients with age group between 16 and 60 years.

2. Diagnosed patients of Oral Submucosal Fibrosis (OSMF).

3. Patients of both sex.

\section{Exclusion Criteria}

1. Patients who are contraindicated for Gandusha e.g.- unconscious, poisoned, weak, krusha person, patient suffering from bleeding disorders and conjunctivitis.
2. Extensive fibrosis with severe trismus with an Inter Incisal Distance (IID) $<15 \mathrm{~mm}$.

3. Disease is most advanced with premalignant and malignant changes.

4. Generalized fibromatosis.

5. Oral manifestation of scleroderma.

6. Oral lichen planus.

7. Pale oral mucosa of anemia mimicking blanching.

8. Chronic debilitating conditions such as Diabetes Mellitus, Hypertension, HIV, etc.

\section{Assessment Criteria}

\section{Subjective Parameters}

\begin{tabular}{|l|l|}
\hline Mukhdaha (Burning sensation in mouth) & Score \\
\hline Nil & 0 \\
\hline On Taking Spicy food & 1 \\
\hline On taking food & 2 \\
\hline Continuous & 3 \\
\hline Lalastrava (Salivation) & Score \\
\hline Normal & 0 \\
\hline Altered & 1 \\
\hline Decreased & 2 \\
\hline Rasagyana (Taste) & Score \\
\hline Normal & 0 \\
\hline
\end{tabular}




\begin{tabular}{|l|l|}
\hline Altered/decreased & 1 \\
\hline $\begin{array}{l}\text { Katu Rasa Asahishnuta (intolerance to food in comparison to } \\
\text { previous tolerance) }\end{array}$ & Score \\
\hline Nil & 0 \\
\hline Mild & 1 \\
\hline Moderate & 2 \\
\hline Severe & 3 \\
\hline Mukha Vedana (pain in mouth) & Score \\
\hline Nil & 0 \\
\hline While opening the mouth & 1 \\
\hline Continuous & 2 \\
\hline Ulceration in Mouth & 25 \\
\hline & Score \\
\hline Mild & 0 \\
\hline Moderate & 1 \\
\hline Severe & 2 \\
\hline Colour of Mucosa & 3 \\
\hline Pink (Normal) & Score \\
\hline Red or deep pink & 0 \\
\hline Red or deep pink & 1 \\
\hline Blanched white & 2 \\
\hline Fibrous bands-on palpation & 3 \\
\hline No fibrous bands & Score \\
\hline One or two solitary fibrous bands & 0 \\
\hline Bands felt nearly in entire surface & 1 \\
\hline Adherent fibrous bands producing rigidity of mucosa & 2 \\
\hline & 3 \\
\hline
\end{tabular}

\section{Objective Parameters}

Scoring pattern for Inter Incisal Distance (mm) ${ }^{3,23}$

The exact readings will be taken with the help of Vernier caliper.

Inter Incisal Distance (IID)

41 or above considering normal

$37-40$

33-36

29-32

25-28

$21-24$

$17-20$

$13-16$

Statistical Methods: Paired t test and Wilcoxon had been used for analyzing data.

\section{DISCUSSIONS}

Age wise distribution: Higher incidence of OSMF was recorded in the age group of 40-60 (64\%). This may be due to prolonged exposure to the tobacco chewing and exposure to other irritants.

Gender wise distribution: Showed higher incidence of OSMF were recorded in Males (68\%). This may be 
a topographic presentation or may be due to the seriousness of the complaints were more in the male or may be the female cases were keeping away from the Hospital due to ignorance.

\section{Occupation wise distribution}

Incidence of OSMF were recorded in the occupation of Employees (28\%), Self-Employers (24\%) and Farmers (20\%). This may be due to work life balance and due to uncontrolled habits.

\section{Diet wise distribution}

$67 \%$ patients belonged to mixed diet group and $23 \%$ to vegetarian. Occurrence were found to be higher in people having a mixed dietary. As non-veg diet consumption showed higher in topographic area in the present study.

\section{Prakruti wise distribution}

Maximum number of patients i.e. $40 \%$ belonged to Pitta Prakruti. It suggests that Pitta Prakruti people are more prone to OSMF may be due to the Sevena of Katu, Amla and Ruksha Rasa.

\section{Saarata wise distribution}

Maximum number of patients i.e. $48 \%$ belonged to Madhyam-Saarata.

\section{Addiction (Vyasana wise distribution)}

Maximum number of patient's i. e. $68 \%$ were having Gutakha; 64\% were having Paan and 60\% were having Tobacco as addiction. Tobacco and Gutakha contain Nicotine with that other toxic contents and the Katu-Kashaya Pradhan Rasa Dravyas leads to increase Stambhana and Shotha (blanching) of oral mucosa leading to OSMF.

Mukhadaha: There was significant change in Mukha$d a h a$, this was probably may be due to the Snigdha, Guru-Guna; Sheeta Virya and Madhur Vipaka of Gow-dughdha.

Lalasrav: There was significant change in Lalasrava, this may be due to Kshalana Swabhava of the Amla Rasa and the Tikshana Guna the Strotovibandha bheda got removed locally hence increasing the $L a$ lasrava.
Rasagyan (Taste): There was significant change in Rasagyan, may be due to removal of the Mukhaliptata and escalation in the lalasrava was seen. This was may be due to the Amla Rasa, Vishyandana and Chedana Karma of Saindhava generating the desired result.

Katu Rasa Asahishnuta: Panchagavya Shukta has the action of Shodhana and Ropana on the oral mucosa and sub mucosa. This healing effect repairs the mucosa and the normal function of oral mucosal epithelium are restored. This increases the tolerance to the Katu Rasa caused by local irritation. In spite of Shukta the Panchagavya contains partial softness of Goghruta and adequate supply of B6, B8, B12 which are locally absorbed from oral mucosa and restoring the deficiency.

Fibrous Bands-On Palpation: Drug Panchagavya Shukta due to the Sanghata Bhedana Guna of Amla and Vishyandana Guna of Lavana added with the supporting Tikshna Guna causes the removal of micro tubules and their hardening in the connective tissue resulting in the fibrolysis. i.e reduction of fibrous band.

Mukha Vedana (Pain In Mouth): Panchagavya Shukta due to the Vaatashmaka action previously explained in the Katurasa Sahishuta and fibrous band reduction repairs the oral wounded mucosa and the Vedana was reduced.

Ulceration In Mouth: Drug Panchagavya Shukta has the overall action of Ropana on the wounded mucosa. As a result Ulceration in the Mouth was reduced.

Colour Of Mucosa: Due to Varnya Guna of Haridra and Tulasi, repairing of the oral mucosa was seen and thus the Colour of mucosa turns to normal.

Inter Incisal Distance (IID): Drug Panchagavya Shukta has the fibrolytic action in the process of repairing the oral mucosal and submucosal wounds. The result is in the form of eased out jaw movements and measured as the increased Inter incisal distance. 


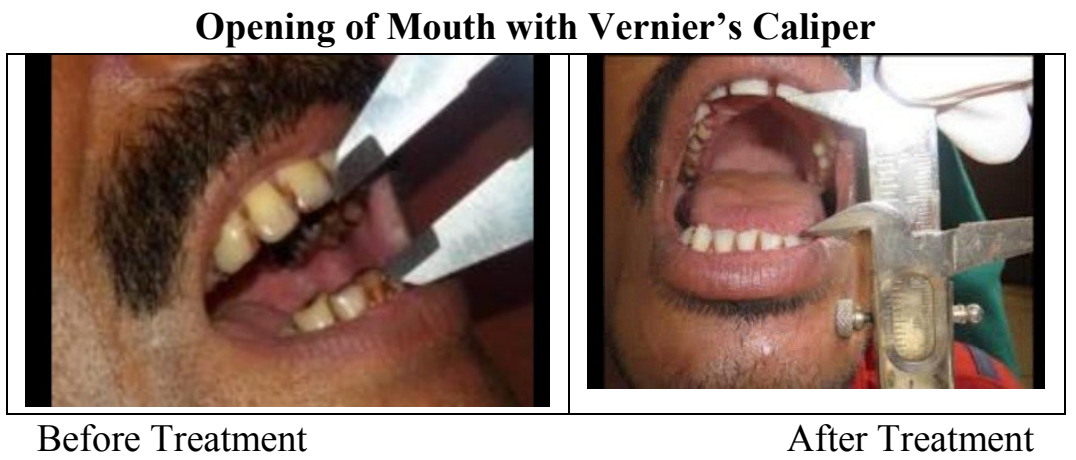

\section{Mode of action of Panchagavya Shukta}

As Panchagavya Shukta are having the properties of Chedhan, Bhedana and Lekhna, Kshalana and Ropan Karmas it helped in reducing the symptoms mentioned in OSMF. Oral sub mucosal fibrosis is a typical connective tissue disorder the, local treatment Comprises of Snehana or Rukshana and Swedana. Snehana is not indicated in the Saama Avastha, Rukshana may be done by Udgharshana or the Amla-Sweda or any other suitable type of Ruksha Sweda. The Snehana is indicated in Niraam avastha and should be done with Ishata-Snighda-Dravya. Swedana. As spread out state of subdermal thickening occurs, Parisheka and Awgaha type of Sweda are indicated. The Vishaghna ac- tion of the Panchagavya is well known and recognized by the treatises and was used to combat the local irritation and deposition of the toxins. As Shukta are having the properties of Vishada, Ruksha, Shodhana Guna this was selected and prepared by adding Haridra, Rajika, Tulasi and Saindhav to potentiate the Vishada and Shodhan, Krumighna and Swedopaga actions. Thus, it gives the fibrolytic action on submucosal thickening and Anti-inflammatory action by dissolving the consolidating subdermal oedema getting absorbed into the blood and gets removed from the body via the colon by the normal physiological curable action. Thus, it gives the significant relief based on the above-mentioned principal.

Fig 2: Before Treatment, After treatment
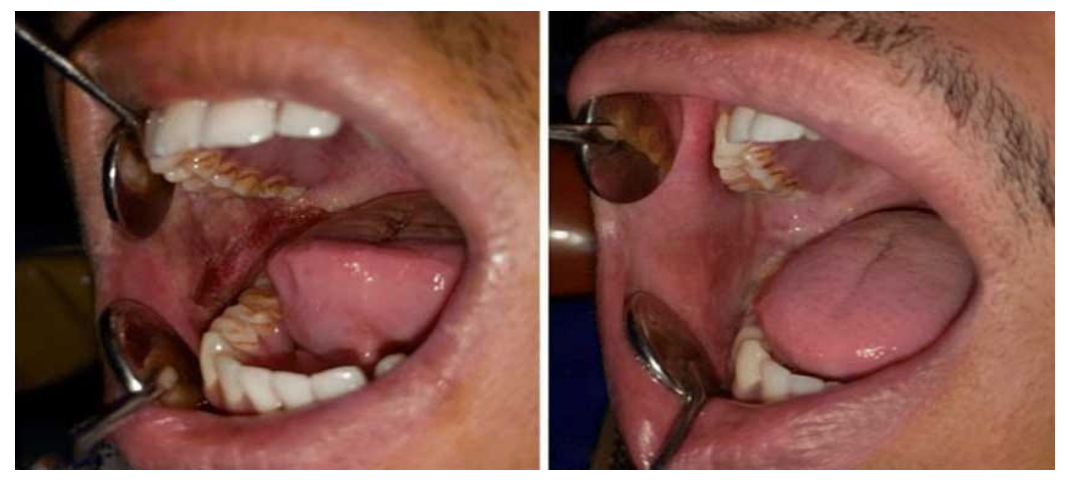

Before and After Treatment with Panchagavya Sukta shodhan Gandusha

\section{CONCLUSION}

As ancient Acharya included Gandoosh in Dinachar$y a$ has an important measure for maintaining oral health. Habit related to oral hygiene Tobacco, smoking, is the major causative factor and Pradnyaparadha is cause of
Addiction. Eating spicy food with Rooksha, Tikshna, Vidahi and Abhishyandi Guna. (Raktadushtikar Ahar as mentioned in the Vatarakta Nidana) Panchagavya Shukta with its Amla Rasa, vipak, Ushna Virya, Tikshna \& Sara Guna helps in Restoration of total health of mucosa. This is Shodhana and Ropana form of Gandoosh described in the text. We have found it to 
be most effective in the Vrana and Vranavastu like conditions Mukhagata Uttana Vatarakta (OSMF).

\section{REFERENCES}

1. Medically reviewed by Christine Frank DDS on December 3, 2015 - Written by The Health line Editorial Team.

2. Smokeless tobacco (paan and gutkha) consumption, prevalence, and contribution to oral cancer, Epidemiol Health. 2017; 39: e2017009. Published online 2017 Mar 9. doi: 10.4178/epih.e2017009 ; PMCID: PMC5543298 PMID: 28292008.

3. Oral submucous fibrosis: Newer proposed classification with critical updates in pathogenesis and management strategies Natl J Maxillofac Surg. 2017 JulDec;8(2):89-94.

doi: 10.4103/njms.NJMS 32 17PMID:29386809PMCID:P MC5773997DOI:10.4103/njms.NJMS 327.

4. More C, Asrani M, Patel H, Adalja C. Oral submucous fibrosis - a hospital-based retrospective study. J Pearldent. 2010;1(4):25-31.

5. Ashtang Sangraha Sutrasthan Tika. Dr. Ravi Dutta Tripath 31/5-9 p.552.

6. More CB, Gupta S, Joshi J, Varma SN (2012) Classification system for oral submucous fibrosis. J Indian Acad Oral Med Radiol 24(1):24-29.

7. Charka Chikitsa -29/19-20 (Chakrapani Tika), Chapter (Vaatarakta).

8. Charka Sutrasthan (18/46) Chapter (Kintah Shirsiya).

9. Ashtang Sangraha Sutrasthan Tika.Dr.Ravi Dutta Tripath 31 Chapter (Gandushadividhimadhyaya).

10. Rasendra Sambhava - (2/42) by Pt.Vishwanatha Dwivedi 'Vaidya'.

11. Rasatarangini Pranacharya Shri Sadananda shrmana Vivarchita - (2/22) by Pt. Kasshinathshastrina.

12. (Ayurvedic Pharmacopoeia on India, 2008) chapter 1 page-19,20.

13. Sharngdhar - Samhita Madhyamkhanda(10/7-9) by Pt. Sharngdharacharya son of Pt. Damodara with commentary. page. 234.

14. Ibid. Sharangadhara: Sharangdhar Samhita, UttaraKhanda 10/19-20, page. 355 .

15. 19. Ibid. Sushruta: Sushruta Samhita, Chikitsasthana 40/65-67, page.558).

16. Ibid. Sushruta: Sushruta Samhita, Chikitsasthana 40/63, page. 558 .

17. Ibid. Vriddha Vagbhatt: Ashtanga Hrudaya, Sutrasthana 22/10-11, page.299-300.

18. Ibid. Vagbhatt: Ashtanga Sangraha, Sutrasthana 31/1012, page.224 16. Ibid. Sharangadhara: Sharangdhar Samhita, UttaraKhanda 10/6-7, page.353).

19. A pilot study on Ayurvedic management of oral submucous fibrosis.- Kundan R. Patel, Manjusha Rajagopala, Dharmendrasinh B. Vaghela, and Ashok Shah $^{1}$ Ayu. 2015 Jan-Mar; 36(1): 34-40. doi: 10.4103/0974-8520.169018PMCID:

PMC4687236PMID: 26730136.

20. Bhavprakasha Purvakhanda Vidyodtini tika 5/44 page. 112.

21. Ashtang Sangraha Sutrasthan Tika.Dr.Ravi Dutta Tripath $31 / 7$ page. 552 .

22. Tulasi a magical herb and a boon for management of oral submucous fibrosis: a clinical study G. Madhulatha*, N. Vijayalaxmi, T. Harshavardhan Department of Oral Medicine and Radiology, Meghna Institute of Dental Sciences, Nizamabad, Telangana, India Received: 15 September 2017 Accepted: 19 September 2017.

23. Clinical evaluation of the role of tulsi and turmeric in the management of oral submucous fibrosis: A pilot, prospective observational study. Adit Srivastava, Rahul Agarwal, T. P. Chaturvedi, Akhilesh Chandra, and O. P. Singh J Ayurveda Integr Med. 2015 Jan-Mar; 6(1): 45-49.doi: 10.4103/0975-9476.146563.

24. Oral submucous fibrosis: Newer proposed classification with critical updates in pathogenesis and management strategies. Deepak Passi, Prateek Bhanot, Dhruv Kacker, Deepak Chahal, Mansi Atri, and Yoshi Panwar Natl J Maxillofac Surg. 2017 Jul-Dec; 8(2): 89-94. doi: 10.4103/njms.NJMS_32_17.

25. Manual of Clinical Otorhinolaryngology; Clinical methods and examination in E.N.T. Khalid A AlAbdulhadi: Zakir Hussain; Ahmed H El Beltagi;Beena Thomas (Chapt.No.3 - Clinial Evaluation of Oral Cavity and Oropharynx. Pg. no-80).

26. Dravyaguna Vijnyan Ayurvedic Medicinal Plants by Prof Dr A P Deshpande. Prof Dr Subhash Ranade Pg no-390.592,569,571,768,

\section{Source of Support: Nil \\ Conflict of Interest: None Declared}

How to cite this URL: Jaiminikumar Shashank Rasane et al: Management Of Oral Submucosal Fibrosis (Osmf) With Panchgavya Shukta Shodhan Gandusha As A Dinacharya Procedure. International Ayurvedic Medical Journal \{online\} 2021 \{cited January, 2021\} Available from: http://www.iamj.in/posts/images/upload/91 99.pdf 